\title{
The Relationship Between Teachers' Inclusion-Related Knowledge, Skills, and Attitudes and Student Outcomes: A Review of Recent Literature
}

\author{
Daniel B. Robinson and David Young \\ St. Francis Xavier University
}

\begin{abstract}
In this article, we report on a scoping review of empirical literature addressing the relationship between teachers' inclusion-related knowledge, skills, and attitudes and student outcomes. Using six common electronic databases for education (ProQuest, JSTOR, SAGE Journals Online, ScienceDirect, PsycINFO, PsycARTICLES), we searched for peerreviewed, English-language publications between 1 January 2008 and 1 January 2018 (a 10-year period). A total of 25 articles met the search criteria for this scoping review and were consequently subject to a more detailed examination. This more detailed examination focused upon five student variables (intellectual disabilities, learning disabilities, autism spectrum disorder [ASD], other mental health disorders, and giftedness) and five possible student outcomes (social well-being, functional or life skills, academic achievement, post-secondary transitions, and exceptionality-related outcomes). These 25 articles include eight systematic or scoping reviews, two that report on experimental studies, nine that report on quasi-experimental studies, and six that report on correlationaldescriptive research studies. A summary account of these 25 articles is offered, as is a list of related implications, for both practice and inquiry. Some of the most significant implications are related to the limited body of evidence related to a number of variables; these include teachers' attitudes and resultant student outcomes, giftedness, and post-secondary transitions. Additionally, these implications also offer cautionary considerations related to teachers delivering mental health-related programs and utilizing technology-related interventions for students with ASD.
\end{abstract}


The successes and failures of inclusive education are, admittedly, dependent upon a whole host of factors. Indeed, the breadth of topics related to inclusive education and the circumstantial settings in which they exist make many wholesale proclamations or suggestions for practice untenable pursuits. Nevertheless, there are several elements that make successful inclusion more possible. These elements include the important supportive and facilitative efforts and roles played by various people in the lives of students with exceptionalities. Such people include, for example, parents or guardians (Waddington \& Reed, 2006), paraprofessionals (Tews \& Lupart, 2008), and principals and other school administrators (Praisner, 2003). Moreover, other influencing elements, less related to individual people and more related to other contextual factors, include educational policies and legislation (Loreman, 2007), pre-service and in-service teacher training programs (Harvey, Yssel, Bauserman, \& Merbler, 2010; Seçer, 2010), and physical environments (Pivik, McComas, \& Laflamme, 2002).

Teachers, including specialist special education teachers (SETs) and generalist mainstream education teachers (METs), can also serve as facilitators (or barriers) to successful inclusion (Fuchs, 2010; Savolainen, Engelbrecht, Nel, \& Malinen, 2012). More specifically, teachers' knowledge (e.g., Van Reusen, Shoho, \& Barker, 2001), skills (e.g., Cheney \& Barringer, 1995), and/or attitudes (e.g., Cross, Traub, Hutter-Pishgahi, \& Shelton, 2004) can have an impact upon the successful implementation of an inclusive learning environment for students with exceptionalities.

While the successful implementation of an inclusive educational environment might be evaluated in any number of ways, the resultant outcomes for students with exceptionalities are especially suitable responding variables to be considered. To be clear, there are other possible measures of success (related, for example, to all students' experiences). However, a focus upon student outcomes specifically for those students who have exceptionalities allows for a more genuine and purposeful alignment of intended individual and group outcomes with inclusion's principal raison d'être. These intended individual and group outcomes might be related to familiar goals of inclusive education including, for example, social well-being, functional and life skills, academic achievement, and/or post-secondary transitions. They may also be more individual- or exceptionality-related. For example, intended outcomes for students with depression might focus upon decreasing the intensity or frequency of feelings of isolation or depression.

Given our understating of the important role of teachers and the desired outcomes for students with exceptionalities, we have aimed to consider recent research literature, so that we might be enabled to answer the following question: What is the relationship between teachers' knowledge, skills, and attitudes in inclusive education and student outcomes?

\section{Scoping Review}

To better understand the relationship that exists between teachers' inclusion-related knowledge, skills, and attitudes and student outcomes, we completed a scoping review of recent literature that focused upon empirical evidence related to these variables. Unlike more traditional systematic reviews, a scoping review offers a "snapshot" of a specific topic (Booth, Papaioannou, \& Sutton, 2012) rather than a critical assessment of research quality. Accordingly, note that this review is meant to be a charting venture, rather than 
an evaluative one. This scoping review provides a map of the relevant literature (Anderson, Allen, Peckham, \& Goodwin, 2008) so that a synthesis of findings may, in turn, become more possible. Indeed, it is meant to "provide an initial indication of the location of the literature relating to a particular issue and to identify its overall size" (Anderson et al., 2008, p. 7). Moreover, our undertaking of this literature review has allowed us to meet two previously identified reasons for selecting a scoping process (see Arksey \& O'Malley, 2005): (a) we examine the extent, range, and nature of research related to a topic, and (b) we summarize and disseminate these research findings.

\section{Methods and Parameters}

Our search was limited to English-only peer-reviewed research literature that investigated the relationship between teachers' knowledge, skills, and attitudes in inclusive education and student outcomes. More specifically, we completed a search of all research articles published between 1 January 2008 and 1 January 2018 (a 10-year period). The rationale for focusing upon this relatively narrow temporal period was our desire to uncover the most recent research evidence related to our question. Limiting our search to this 10-year period also helped us ensure that located research was most likely to have been conducted within the current education milieu (e.g., with current curricula, policies, legislation, etc.). Search terms included teacher (in abstract) and knowledge OR skill OR attitude (in abstract) and inclusion OR inclusive (in abstract) and outcome (in all text), as we believed they best captured the variables within our initial question. Databases that we utilized include ProQuest, JSTOR, SAGE Journals Online, ScienceDirect, PsycINFO, and PsycARTICLES because they, together, encompass a comprehensive catalogue of inclusive education-related literature. These database searches occurred between February 14, 2018, and March 16, 2018.

Teacher variables. Teacher variables were identified and categorized as one or more of the following: (a) knowledge, (b) skills, and (c) attitudes. These three variables were chosen because they have a history of focused importance within education (e.g., Darling-Hammond \& Baratz-Snowden, 2000; Shulman, 1987) and because they are categories of familiar teacher traits or competencies recognized within teacher education programs (e.g., Casey \& Childs, 2007; Cook, 2002) and provincial teacher certification bodies (e.g., Government of Alberta, 2013; Ontario College of Teachers, n.d.). Moreover, they are also targeted outcomes of in-service teacher education professional development programs (e.g., Desimone, 2011).

Student variables. Student variables were identified and categorized as one or more of the following: (a) intellectual disabilities (IDs), (b) learning disabilities (LDs), (c) autism spectrum disorder (ASD), (d) other mental health disorders, and (e) giftedness. Though these exceptionalities do not provide an exhaustive list of possibilities to be found within school communities, we have focused upon them, and in this manner, for several reasons. First, learning difficulties (related, often, to IDs, LDs, ASD, and/or another mental health disorders) have been found to be the most common aspect of special educational needs (Croll \& Moses, 2003). Second, our inclusion of "other mental health disorders" is meant to be responsive to the observation that there is an increasing focus upon addressing students' mental health within schools (Reinke, Stormont, 
Herman, Puri, \& Goel, 2011) — and many other exceptionalities can be classified as other mental health disorders. Third, our inclusion of "giftedness" is meant to be responsive to the observation that giftedness is oft neglected (Koshy \& Robinson, 2006) and that gifted students' unique social and emotional needs are often unrecognized or denied their existence (Petersen, 2009).

Student outcomes. Student outcomes were identified and categorized as one or more of the following: (a) social well-being, (b) functional or life skills, (c) academic achievement, (d) post-secondary transitions, and (e) exceptionality-related (e.g., intensity or frequency of feelings of isolation or depression for a student with depression). We focused upon these outcomes because we believe they are especially familiar to those working within contemporary school communities with inclusive education goals and/or programs. Moreover, we also see these same sorts of desired outcomes suggested and disseminated by others within local and global educational communities (e.g., Canadian Association for Community Living, n.d.; United Nations Educational, Scientific and Cultural Organization [UNESCO], 2009).

Research designs. Research designs were identified and categorized as one of the following: (a) systematic or scoping review, (b) experimental, (c) quasi-experimental, and (d) correlational-descriptive. These categories enabled a consideration of a broad spectrum of research designs and possibilities (i.e., some of these research studies would likely have been excluded if subject to a systematic review process). Still, to provide clarity and transparency, we have categorized the research designs in this way, as has been suggested by Arksey and O'Malley (2005). While we are not, herein, privileging particular research designs over others (nor are we providing a critical consideration of these specific implemented research designs), we do recognize the evidence hierarchies that exist, particularly within many health- and education-related research milieus (see Barnhouse Walters, Lareau, \& Ranis, 2009; Creswell, 2005; Glasziou, Vandenbrouke, Chalmers, \& Lind, 2004).

\section{Search and Review Results}

The initial search resulted in 1,301 articles (1,093 once all close duplicates were removed). All articles' titles and/or abstracts were first read by a lone research assistant to determine if the research: (a) focused on at least one of three teacher variables (knowledge, skills, or attitudes), (b) focused on students with at least one of five identified exceptionalities (IDs, LDs, ASD, other mental health disorders, or giftedness), and (c) focused on at least one of five student outcomes as a variable (social well-being, functional or life skills, academic achievement, post-secondary transitions, or exceptionality-related [e.g., improvement in symptoms related to a health disorder]). If the research assistant was unsure about including or excluding an article, he was instructed to include it until it could be subsequently considered by the two of us. This process resulted in the exclusion of 1,006 articles. The remaining 87 articles were read in their entirety to determine whether they met these same criteria. This secondary process was done, independently, by a research assistant and one of us (Robinson). In cases where both the research assistant and Robinson agreed, articles were included or excluded as appropriate. In the cases where there was not an initial agreement, the 
research assistant and Robinson invited the other co-author (Young) to participate in the review. Then, follow-up discussions occurred until there was unanimous consent to include or exclude the remaining articles. This resulted in an additional 62 articles being excluded because they did not address one of the five listed student variables and/or one of the five student outcomes, leaving 25 articles to be subject to a more comprehensive review. This entire search process is illustrated in Figure 1.

Figure 1. Review Process and Results

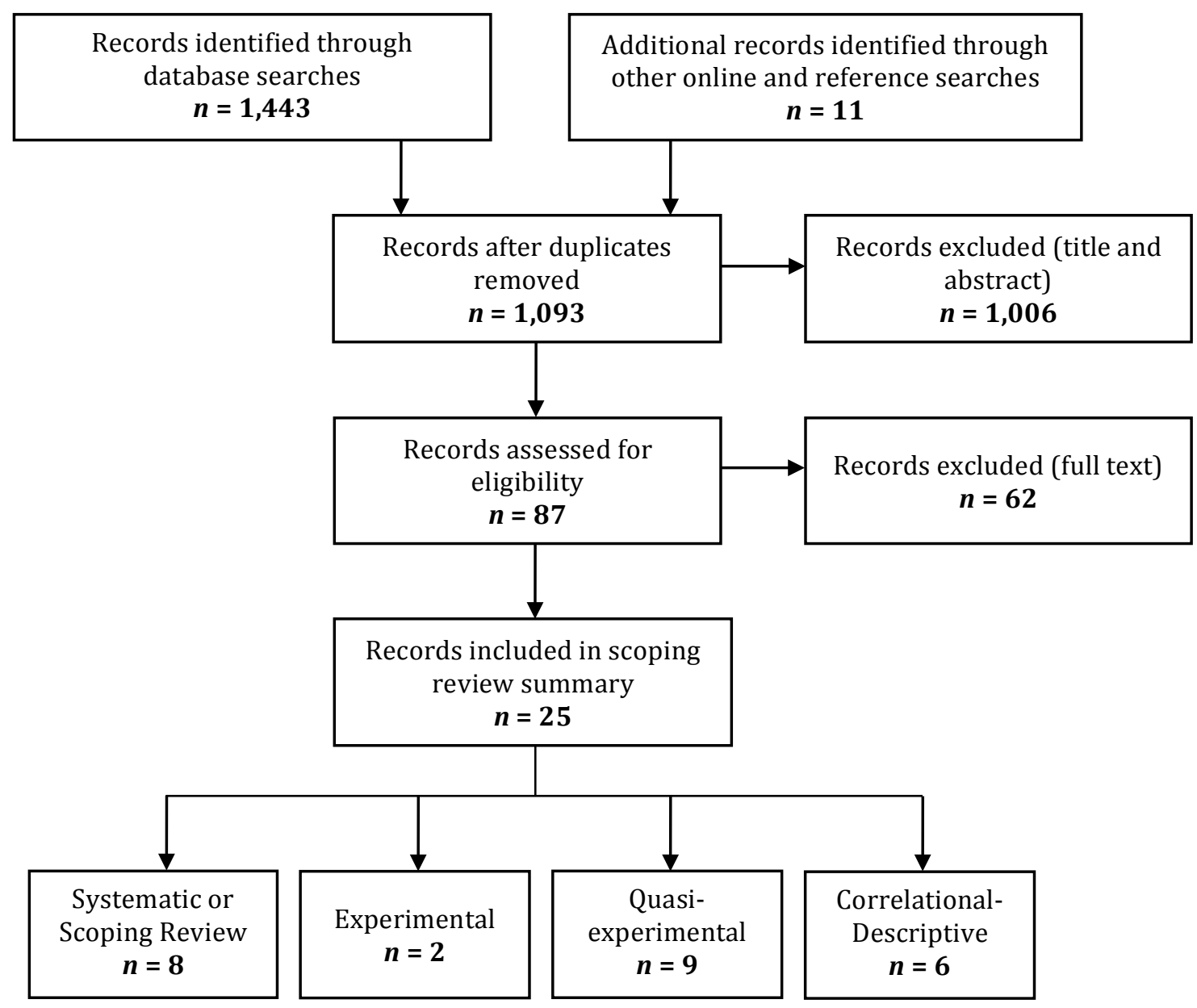

The majority of the 25 studies ( $n=15$ ) occurred in the United States (or, in the case of reviews, were authored by scholars at American universities). All the other studies and reviews were from other Western nations, including four from Australia and one from each of Canada, Great Britain, Greece, Netherlands, Sweden, and Switzerland.

Almost all the research articles focused on more than one closely related teacher variable. Specifically, most focused upon teachers' knowledge and skills $(n=18)$ related, for example, to teaching with a program intended to be responsive to students' 
exceptionalities. Only a small number of research articles focused upon teachers' attitudes, alone $(n=3)$ or alongside other teacher variables $(n=3)$.

Student variables included IDs $(n=7)$, LDs $(n=2$; e.g., dyslexia), ASD $(n=12)$, and other mental health disorders $(n=8$; e.g., emotional and behavioural disorders, depression, speech delay, anxiety, attention-deficit/hyperactivity disorder [ADHD], oppositional defiant disorder [ODD]). No research studies were found that focused upon giftedness. While most research studies focused upon a single student variable, three focused upon two or more student variables. That is, Bottge et al. (2015) focused upon IDs, LDs, ASD, and other mental health disorders; Coleman, Hurley, and Cihak (2012) focused upon IDs and ASD; and Hong, Shaffer, and Han (2017) focused upon ASD and other mental health disorders (speech delay).

Student outcomes were related to social well-being $(n=7)$, functional or life skills $(n=8)$, academic achievement $(n=17)$, and/or they were exceptionality-related $(n=5)$. While some research studies focused upon a single student outcome $(n=12)$, others focused upon two or more student outcomes $(n=13)$. No research studies were found that focused upon post-secondary transitions. See the Appendix for a summary overview of these 25 research studies.

\section{Types of Studies and Their Exceptionalities-Related Conclusions}

Eight of the research articles found reported on results from systematic $(n=6)$ or scoping $(n=2)$ literature reviews. Two reported on studies that employed true experimental research designs while nine reported on studies that employed quasiexperimental research designs. Finally, six reported on studies that were correlational and/or descriptive in design.

Systematic and scoping reviews. Together, the six systematic reviews considered 215 different research studies or trials. Three of these six focused on research related to ASD (related to 132 different research studies or trials), while three focused upon other mental health disorders (depression, anxiety, ADHD). Though one of the two scoping reviews considered 20 studies or trials, the other considered six other reviews. Given this many studies or trials, there is plenty of documentary evidence related to some of the variables considered. That is, results from these reviews might provide the strongest evidence related to the initial question. Some of the most noteworthy conclusions are related to other mental health disorders (depression, anxiety, ADHD), ASD, and IDs.

Other mental health disorders: depression. Calear and Christensen's (2009) systematic review considered school-based prevention and early intervention programs for depression. All the intervention programs required teachers (and/or other leaders) to first gain the requisite knowledge and skills to deliver the program. Their review focused upon 42 randomized controlled trials related to 28 different school-based programs. While $33 \%$ of the programs they considered had multiple program leaders (including four in which teachers were co-leaders), 10 were led by a teacher alone. Teacher-led programs led to a significant reduction in student depression in only six trials (i.e., 46\%). In fact, trials utilizing teachers produced both fewer and smaller significant positive effects than did those with different leaders. Relatedly, and perhaps more importantly, Calear and 
Christensen also concluded that such a finding "suggests that programs are more effective in the hands of mental health professionals ... and that there is a need to establish whether the specific training of classroom teachers can lead to improved outcomes" (2009, p. 435). These findings suggest that while trained teachers may be the most costeffective way of delivering depression-related interventions, they are certainly not the most effective.

Other mental health disorders: anxiety. Neil and Christensen's (2009) systematic review considered school-based prevention and intervention programs for anxiety. Again, all the intervention programs required teachers (and/or other leaders) to first gain the requisite knowledge and skills to deliver the program. Their review focused upon 27 outcome trials, related to 20 different programs. Teachers were program leaders (as co- or sole leaders) in $24 \%$ of the trials. Unlike what was found by Calear and Christensen (2009), Neil and Christensen found that significant effects did not depend on the type of program leader (i.e., teacher or non-teacher). Their conclusion, then, was that this "may suggest that compared to depression programs, anxiety programs may be the intervention of choice in school environments" (Calear \& Christensen, 2009, p. 212). That is, trained teachers are suitable individuals to deliver anxiety-related programs for children and youth in school communities.

Other mental health disorders: ADHD. Sherman, Rasmussen, and Baydala's (2008) review considered the impact of teacher factors upon achievement and behavioural outcomes of students with ADHD. Their review focused upon 14 studies. They found that teachers' knowledge, skills, and attitudes (related, for example, to knowledge of intervention techniques) can have an impact upon student success. More specifically, they found "teacher factors, broadly defined, can significantly impact a variety of outcomes among students with ADHD” (Sherman et al., 2008, p. 356). Still, despite Sherman et al.'s findings, they also suggested additional research is needed to understand these relationships.

ASD. Three of the systematic reviews focused upon ASD (Knight, McKissick, \& Saunders, 2013; Parsons et al., 2011; Pennington, 2010). In all, these reviews considered 132 studies. Knight et al. (2013) considered technology-based interventions, Parsons et al. (2011) considered best practice in educational provision, and Pennington (2010) considered computer-assisted instruction (CAI) - all as they relate to students with ASD. In all studies reviewed, teachers' knowledge and skills were considered alongside resultant outcomes for students. Given their systematic review findings related to technology interventions for students with ASD, Knight et al. (2013) offered the following cautionary note:

IPads [sic], iPods, iPhones, and Smartboards are becoming standard instructional tools in classrooms across the county. The rapid emergence of new technologies combined with anecdotal reports of miraculous results may cause some teachers to jump on the technology bandwagon. Unfortunately, the field of ASD seems especially vulnerable to miraculous claims, fantastic fads, and unproven approaches (Simpson 2005). Since there were so few studies found in the current review that used these instructional tools and the findings suggest a low to moderate level of empirical support for using technology-based interventions to teach academic skills, teachers are urged to weigh the benefits of using such technologies with overall student outcomes. (p. 2646) 
Somewhat contradicting this position, Pennington found that teachers with the requisite knowledge and skills to facilitate students' CAI had a positive effect upon academic achievement. Lastly, Parsons et al. (2011) found that there is insufficient information to conclude that teachers' knowledge or skills, related to any one type of technology-related intervention, ought to be considered over any others.

Additionally, Simpson and Keen (2011) completed a scoping review that considered music interventions for students with ASD; their review focused upon 20 articles. They found that there is limited evidence suggesting teachers with requisite knowledge and skills to utilize music as an intervention can facilitate improvements in social, communicative, and behavioural skills in students with ASD.

IDs. Categorized herein as a scoping review, Solis, Vaughn, Swanson, and McCulley (2012) referred to their work as a summary of syntheses. The six syntheses they considered represented 146 separate studies that focused upon inclusion or coteaching. While they found some evidence of teachers' knowledge and skills having a positive impact upon students, the superiority of some inclusion models or interventions over others could not be established. Irrespective of inclusion models or interventions, teachers consistently reported the need for their own training if their practice was to have a positive impact upon students with different IDs.

Experimental designs. Only two research articles reported on studies that employed true experimental designs. Bottge et al. (2015), by way of a between-subjects (post-test only) design, investigated the impact of enhanced anchored instruction (EAI) on students with and without "math disabilities" (MDs). Additionally, Östberg and Rydell (2011), by way of a between-subjects (pre-, post-, and follow-up test) design, investigated the efficacy of a combined teacher-parent management training program for students with ADHD.

IDs, LDs, ASD, and other mental health disorders. Bottge et al.'s (2015) experiment included students with many exceptionalities. Indeed, all categories of student variables, save giftedness, were included within their research. These four exceptionality categories were labelled, as appropriate, as MDs by the researchers. This is something also done by others whose work focuses upon exceptionalities and math education (e.g., see Swanson \& Jerman, 2006). Students who were taught by teachers who had the requisite knowledge and skills to offer EAI improved in their academic achievement in content related to fractions, computation, and problem-solving skills in mathematics. This was true of students with and without MDs. Moreover, students with MDs in the intervention group (i.e., students with teachers who delivered EAI) outperformed students with MDs in the control group. These results suggest that equipping teachers with the knowledge and skills necessary for delivering EAI can have positive results, related to mathematics academic achievement, for students with various MDs.

Östberg and Rydell's (2011) experiment focused more narrowly upon two other mental health disorders: ADHD and ODD. Their study investigated the impact of a combined parent and teacher manual-based group training program. Participation in the program resulted in a reduction in the number of children who met the $D S M-I V$ criteria for ADHD and/or ODD. Effects were less pronounced in school settings than they were in home settings, though they were most pronounced when parents and teachers of the same child took part in the intervention. Lastly, teachers with more problematic 
classroom situations benefited most from the intervention. These results suggest that training teachers with knowledge and skills related to a lone and specific intervention can have a positive impact upon students with ADHD or ODD. Moreover, such positive impacts may be more likely when teachers work alongside parents who have access to the same training.

Quasi-experimental designs. Nine of the 25 research studies employed quasiexperimental designs. Three of them focused upon IDs, five focused upon ASD, and one focused upon other mental health disorders. The three studies focusing upon IDs and the five studies focusing upon ASD considered students' social well-being, functional or life skills, and/or academic achievement. The lone study focusing upon other mental health disorders focused upon exceptionality-related outcomes. The number of participants in these quasi-experimental studies ranged from one (Whitcomb, Bass, \& Luiselli, 2011) to 327 (Jorm, Kitchener, Sawyer, Scales, \& Cvetkovski, 2010).

IDs. Dessemontet, Bless, and Morin (2012), Jimenez, Browder, Spooner, and DiBase (2012), and Pennington and Koehler (2017) all investigated the relationship between teachers' inclusion-related knowledge and skills and outcomes for students for whom intellectual ability was a challenge. Dessemontet et al.'s research with students ( $n=68)$ who had an ID found that students with METs who had inclusive education knowledge and skills made slightly more progress in literacy skills than did students taught by SETs in special schools. Similarly, Jimenez et al. found that METs who had been trained with the requisite knowledge and skills to teach with a specific instructional method (i.e., peer-mediated time-delay instruction) could help students $(n=5)$ improve in science learning. Finally, Pennington and Koehler found that SETs, trained with the knowledge and skills related to another intervention, helped students $(n=3)$ improve upon their own academic achievement in literacy-related tasks. Together, these results suggest that purposeful training programs for teachers can lead to positive results for students with exceptionalities, particularly with respect to academic achievement. Moreover, these gains can be realized by METs in "regular" classroom environments. And, sometimes these gains are better there than with SETs in special school environments.

ASD. Radley, Ford, Battaglia, and McHugh (2014), Sainato, Morrison, Jung, Axe, and Nixon (2015), Simpson and Keen (2009), Whalen et al. (2010), and Whitcomb et al. (2011) all investigated the relationship between teachers' inclusion-related knowledge and skills and outcomes for students with ASD. Radley et al. investigated the effects of teachers' knowledge and skills related to a social skills training program on the social engagement of children $(n=4)$ with ASD and found a positive result. Sainato et al. examined the effects of teachers' model inclusive kindergarten programs and found no differences from the control group with respect to test scores. However, students in the model inclusive program did exhibit higher scores in some skill domains. Simpson and Keen's research found that teachers' newly developed knowledge and skills (related to interactive song) facilitated learning. However, they offered no suggestions against generalizing their findings to other contexts. Whalen et al. also found that students $(n=47)$ taught by teachers who developed knowledge and skills related to a specific educational program showed a greater improvement in language and cognitive measures than did those in a control group. Similarly, Whitcomb et al. found teachers who had the 
knowledge and skills to implement a different program could have a positive impact upon their students' reading accuracy and reading skills.

Taken together, these research studies all suggest that teachers' knowledge and skills related to inclusive practices can have a positive impact upon social well-being, functional or life skills, and academic achievement for students with ASD. While such results have not been universally found, and the teachers' knowledge and skills differed in every study, it is clear that teacher-education programs of various sorts can have a positive impact for students with ASD.

Other mental health disorders: general mental health. Jorm et al. (2010) investigated the impact of a mental health first aid course for secondary teachers. The indirect impact of these teachers' newly acquired knowledge, skills, and attitudes on their schools' students was assessed by considering students' mental health, among other measures. Though the training provided to the teachers increased their knowledge and changed their beliefs (e.g., about mental health treatment, stigma, etc.), there were no effects found related to students' resultant mental health. This research, then, offers two important conclusions: (a) improving teachers' knowledge, skills, and attitudes can have some positive impacts upon school communities (related, for example, to disseminating mental health messages to students), and (b) these improvements in teachers' knowledge, skills, and attitudes have not been shown to have a measurable effect upon students' actual mental health.

Correlational-descriptive designs. Six of the studies employed correlationaldescriptive research designs. Two of them focused upon IDs, three focused upon ASD (one alongside other mental health disorders [speech delay] and one alongside IDs), one focused upon LDs (dyslexia), and one upon other mental health disorders (disabilities, generally). Five of the studies considered academic achievement as an outcome. In three of these studies academic achievement was considered as a sole outcome, while in the other two studies academic achievement was considered alongside other outcomes. The number of participants in these correlational-descriptive studies ranged from two (students; Hong et al., 2017) to 400 (teachers; Strogilos \& Stefanidis, 2015). Though we offer no critique within this scoping review related to research quality, it is important to note that most of the authors of these correlational-descriptive studies do offer a caution against assuming causal relationships rather than correlational ones.

IDs, ASD, other mental health disorders. Coleman et al. (2012) compared the effects of teacher-directed instruction on students' $(n=3)$ learning. More specifically, they researched effects of teachers' knowledge and skills related to constant time delay and teacher-created computer-assisted instruction. Two students in the study had IDs while the other had ASD. Though both strategies were effective with respect to academic learning (of sight words), the teacher-directed strategy was more efficient (i.e., learning was faster). Coleman et al. concluded that initial teaching should begin with teacherdirected instruction, with computer-assisted instruction being more appropriate for further practice and reinforcement.

Elliot's (2008) research considered the relationship between teachers' attitudes toward inclusion and the level of academic success in physical education attained by students with IDs compared to their peers without exceptionalities. He found that 
teachers with a positive inclusion attitude provided all students (i.e., those with and without IDs) with more practice attempts, at a higher level of success, and had higher expectations for students with exceptionalities. Elliot also found that teachers' attitudes were closely related to their definitions of student success; teachers and students evidenced a Pygmalion effect, whereby students with exceptionalities conformed to the teachers' different expectations for them.

Hong et al. (2017) investigated how teachers, knowledgeable and skilled to deliver a Reggio Emilia-inspired curriculum, can have some positive effects for children with $(n=2$; ASD, other mental health disorders [speech delay]) and without $(n=3)$ exceptionalities. The lone student participant with ASD improved communication skills while the student with a speech delay showed no improvement. Neither student improved in cognitive skills. Results from this research suggest that most (i.e., four) students improved in relationship, communication, and play skills-improvements that led to increased interest, inclusion, friendship, and empathy for those students without exceptionalities.

Finally, Strogilos and Stefanidis (2015) found that co-teachers who hold favourable inclusive education-related attitudes agree that the learning of students with exceptionalities is improved when they are placed in mixed ability groups. Strogilos and Stefanidis's conclusion was that teachers' attitudes toward the efficacy of co-teaching students with exceptionalities are "positively correlated to their attitudes towards social participation, behaviour improvement and learning progress of students with disabilities" (p. 218).

LDs: dyslexia. Hornstra, Denessen, Bakker, van den Bergh, \& Voeten's (2010) research also focused upon teacher attitudes toward inclusion (specifically, with respect to dyslexia). They found that teachers' implicit dyslexia-related attitudes were related to teacher ratings of student achievement in some areas (i.e., on a writing task and a standardized spelling test) but not in others (i.e., related to mathematics). However, explicit self-reported dyslexia-related attitudes were unrelated to all outcome measures.

\section{Implications and Suggestions for Practice and Inquiry}

A search for recent research literature related to the initial question (What is the relationship between teachers' knowledge, skills, and attitudes in inclusive education and student outcomes?) has uncovered literature that is: (a) largely focused upon teachers' knowledge and skills (together, and generally without also focusing upon attitudes); (b) related, primarily, to IDs, ASD, and other mental health issues; and (c) also related, primarily, to academic achievement - but also to social well-being, functional or life skills, and exceptionality-related outcomes.

This focus upon teachers' knowledge and skills as a multi-variable can most often be viewed as an intervention of some sort, whereby teachers first learn about and how to implement an educational program that is meant to support students with exceptionalities. That is, none of the experimental or quasi-experimental research studies measured teachers' existing knowledge and/or skills and then tried to determine whether these attributes had an impact upon student outcomes. Rather, the common model has been to improve upon teachers' knowledge and skills by way of teacher training and then determine whether that training made a significant difference. Often it did, but not 
always. Additionally, that attitude-related research is largely absent from the literature suggests that few, if any, conclusions can be made about the relationship between teachers' inclusion-related attitudes and student outcomes.

Most of the research focuses upon three of the five categories listed: IDs, ASD, and other mental health issues. The two research studies that attend to LDs provide only minimal informative data and conclusions. Note, too, that one is a multi-exceptionality study and the other is a correlational-descriptive study. Again, giftedness is entirely absent in the literature when teachers' knowledge, skills, and/or attitudes and student outcomes are considered. So, herein there is some useful information related to students' exceptionalities but it, unfortunately, is lacking in these two important areas.

That academic achievement is the most widely considered outcome should not be construed as altogether troublesome. Indeed, student success in academics is a straightforward and logical goal of inclusive education. If academic achievement is to be a primary goal of education and/or of inclusive or special education, this research provides useful information. For the other possible outcomes, evidence is also there, though there is less of it.

Given our summary observations, herein we also offer a small number of suggestions for future practice within $\mathrm{P}-12$ education and teacher education (both preservice and in-service). We also offer a small number of suggestions for future inquiry.

\section{Teachers as Deliverers of Mental Health-Related Programs}

School personnel are increasingly being called upon to deliver a variety of mentalhealth-related programs in school communities (Han \& Weiss, 2005). Indeed, there is some evidence that, when properly developed and implemented, many school-based mental health programs can have positive effects (Han \& Weiss, 2005; Wilson, Lipsey, \& Derzon, 2003). However, this scoping review has shown than equipping teachers with knowledge and skills to deliver some programs focusing upon "other mental health disorders" is not necessarily ideal nor effective. That is, teachers who delivered both depression- and mental-health-related interventions (see Calear \& Christensen, 2009; Jorm et al., 2010) were less effective than were health professionals, or were simply not effective. Given this:

- Pre-service teacher education programs and pre-service teachers as well as educational jurisdictions and in-service teachers must consider that some schoolsite intervention programs (e.g., related to depression or mental health [first aid]) might be best delivered by people other than teachers. Other programs (e.g., related to anxiety) might be best delivered by teachers. Pre-service and in-service teacher training material and human resources should not be (mis)directed to train teachers if others (e.g., health professionals) are better or best suited to deliver the same content.

- Continued research in this area might consider additional exceptionalities and mental health disorders, and it might also focus upon implementation fidelity, particularly by teachers. 


\section{Notable Gaps: Giftedness and Post-Secondary Transitions}

There is a complete absence of recent research literature related to the initial question as it relates to both giftedness and post-secondary transitions. This is despite the observation that gifted education programs continue to be needed, and that there is a continuing absence of challenge for gifted and talented students in schools (Reis \& Renzulli, 2009). And, this absence occurs despite inclusive education within general settings being a predictor of successful post-secondary transitions (e.g., post-secondary education, employment, etc.; Test et al., 2009). Given this:

- The body of evidence reviewed in this scoping review can offer no suggestions for pre-service teacher education programs and pre-service teachers nor for educational jurisdictions and in-service teachers related to the parameters and giftedness and post-secondary transitions.

- Continued research in both of these areas is needed. Specifically, research is needed that considers: (a) teachers' inclusion-related knowledge, skills, and attitudes and student outcomes for gifted students, and (b) teachers' inclusionrelated knowledge, skills, and attitudes and student outcomes related to postsecondary transitions, for all students.

\section{Positive Outcomes Realized with Improved Teacher Knowledge and Skills}

There is plenty of documentary evidence suggesting that teacher training programs that aim to improve teachers' inclusion-related knowledge and skills can have positive outcomes for students with a number of exceptionalities. This is particularly true for students with ADHD (Sherman et al., 2008) and ASD (Pennington, 2010). It is also especially true for outcomes that are closely related to academic achievement. Moreover, this scoping review has also suggested that teachers themselves clearly believe that inservice teacher training is needed if they are to effect positive changes and outcomes for their students with exceptionalities (e.g., see Solis et al., 2012). Given this:

- Pre-service teacher education programs and pre-service teachers as well as educational jurisdictions and in-service teachers need to access training programs that will equip teachers with the knowledge and skills needed to deliver educational programs that are purposefully aligned with the exceptionalities they encounter in practice. While initial teacher education programs might do this by way of broad surveys and/or focused selections of exceptionalities, in-service teachers will need to be able to access continuous and ongoing specific training that aligns with the changing exceptionalities found within their own personalized teaching contexts.

- Continued research in this area might consider teachers' implementation of learned knowledge and skills (e.g., intervention programs) as it relates to professional development models, and also in comparison to other knowledge or skills (e.g., other intervention programs).

\section{Technology and ASD: A Caution}


Notwithstanding the above findings, the research also suggests that teacher training that focuses upon the introduction and implementation of various technologies, particularly with students with ASD, may be misguided. That is, as Knight et al. (2013) and Simpson and Keen (2011) found, there is a relatively low level of empirical support for using technology-based interventions to teach academic skills to students with ASD. This is despite a long history of the use of technology to teach students with ASD (e.g., see Colby, 1973; Mineo, Ziegler, Gill, \& Salkin, 2009). Moreover, others (e.g., Parsons, 2011) found that there is limited research suggesting that some intervention programs are better than others for students with ASD. Admittedly, this may be tied to the often-shared observation related to ASD: If you have met one person with autism, you have met one person with autism (Shore, Rastelli, \& Grandin, 2006). Indeed, different students with ASD will respond differently to different interventions. Given this:

- Pre-service teacher education programs and pre-service teachers as well as educational jurisdictions and in-service teachers need to consider technologybased interventions for students with ASD with a healthy degree of caution. Moreover, because technology use is both costly and potentially ineffective, decisions to use or not use various technologies cannot be left to teachers alone.

- Continued research in this area might consider some of the most commonly used technologies (i.e., used for students with ASD) so that a more robust foundation of empirical evidence might suggest that teachers' knowledge and skills to utilize them will result in some realized gains for students.

\section{Concluding Comments}

Our consideration of this literature has allowed us to offer a summary answer to the question, "What is the relationship between teachers' knowledge, skills, and attitudes in inclusive education and student outcomes?" Our final focus upon four areas, where we offered our own suggestions for practice and inquiry, is meant to offer a potential answer to "So, what?" questions. These suggestions are related to what we see as four of the more common and/or most compelling findings. Others who consider the information presented in the Appendix may see other findings that they would sooner see addressed. And, we would encourage them to do so.

We suspect that we are not alone believing that the things teachers know, can do, and value with respect to inclusion can have a consequence upon students with exceptionalities. We do believe that this scoping review has allowed us to find some support for what was in many ways an intuitive assumption. We are hopeful, then, that our suggestions for practice and inquiry might be taken up by our peers in both schools and the academe - so that continued positive student outcomes and more definitive understandings might be realized.

\section{Limitations}

Notwithstanding the knowledge that has been gleaned by this scoping exercise, we are also aware of some limitations related to our review process and results. These 
limitations are related to the following: (a) our search parameters, and (b) our chosen student variables.

With respect to our search parameters, we recognize that the 10-year period, despite our stated rationale, automatically excludes earlier research studies that may have been conducted within the same sort of context. Though we were purposeful in our search for recent research literature, some might suggest an extended temporal period might have allowed for additional important studies for consideration. We would agree. Furthermore, additional search terms might have resulted in the discovery of additional research studies. That is, though we chose the teacher-competency-familiar terms knowledge OR skill OR attitude for our search, less common yet synonymous search terms might have resulted in the discovery of additional research studies. For example, belief and/or value could have been added as an alternative to attitude. Similarly, cognitive could have been added as an alternative to knowledge.

Our selection of five specific student variables (i.e., IDs, LDs, ASD, other mental health disorders, and giftedness) might present another limitation to some. However, given our purposeful focus upon these five possible categories of exceptionality, we suggest this might be better understood as a delimitation of our scoping review. Still, we recognize that others might provide their own rationales for attending to other or additional exceptionalities. We note that the absence of other exceptionalities within this scoping review does not speak to their absence in the literature. Rather, those exceptionalities were simply outside the scope of our own inquiry.

\section{References}

An asterisk indicates works that were included in the literature review.

Anderson, S., Allen, P., Peckham, S., \& Goodwin, N. (2008). Asking the right questions: Scoping studies in the commissioning of research on the organization and delivery of health services. Health Research Policy and Systems, 6(7), 1-12. doi:10.1186/1478-4505-6-7

Arksey, H., \& O’Malley, L. (2005). Scoping studies: Towards a methodological framework. International Journal of Social Research Methodology, 8(1), 19-32. doi:10.1080/1364557032000119616

Barnhouse Walters P., Lareau, A., \& Ranis, S. H. (2009). Educational research on trial: Policy reform and the call for scientific rigor. New York, NY: Routledge.

Booth, A., Papaioannou, D., \& Sutton, A. (2012). Systematic approaches to a successful literature review. London, UK: Sage.

* Bottge, B., Toland, M., Gassaway, L., Butler, M., Choo, S., Griffen, A., \& Ma, X. (2015). Impact of enhanced anchored instruction in inclusive math classrooms. Exceptional Children, 81(2), 158-175. doi:10.1177/0014402914551742

* Calear, A., \& Christensen, H. (2010). Systematic review of school-based prevention and early intervention programs for depression. Journal of Adolescence, 33(3), 429-438. doi:10.1016 /j.adolescence.2009.07.004

Canadian Association for Community Living. (n.d.). Inclusive education (Pamphlet). Toronto, ON: Author. Retrieved from http://inclusiveeducation.ca/wp-content/uploads/sites/3/2013/07 /Inclusive-Education.pdf 
Casey, C., \& Childs, R. (2007). Teacher education program admission criteria and what beginning teachers need to know to be successful teachers. Canadian Journal of Educational Administration and Policy, 67, 1-24.

Cheney, D., \& Barringer, C. (1995). Teacher competence, student diversity, and staff training for the inclusion of middle school students with emotional and behavioral disorders. Journal of Emotional and Behavioral Disorders, 3(3), 174-182.

Colby, K. M. (1973). The rationale for computer-based treatment of language difficulties in nonspeaking autistic children. Journal of Autism and Childhood Schizophrenia, 3(3), 254-260.

* Coleman, M. B., Hurley, K. J., \& Cihak, D. F. (2012). Comparing teacher-directed and computerassisted constant time delay for teaching functional sight words to students with moderate intellectual disability. Education and Training in Autism and Developmental Disabilities, 47(3), 280-292.

Cook, B. G. (2002). Inclusive attitudes, strengths, and weaknesses of pre-service general educators enrolled in a curriculum infusion teacher preparation program. Teacher Education and Special Education: The Journal of the Teacher Education Division of the Council of Exceptional Children, 25(3), 262-277.

Creswell, J. W. (2005). Educational research: Planning, conducting, and evaluating quantitative and qualitative research (2nd ed.) Upper Saddle River, NJ: Pearson.

Croll, P., \& Moses, D. (2003). Special educational needs across two decades: Survey evidence from English primary schools. British Educational Research Journal, 29(5), 731-747.

Cross, A. F., Traub, E. K., Hutter-Pishgahi, L., \& Shelton, G. (2004). Elements of successful inclusion for children with significant disabilities. Topics in Early Childhood Special Education, 24(3), 169-183.

Darling-Hammond, L., \& Baratz-Snowden, J. (2005). A good teacher in every classroom. San Francisco, CA: John Wiley \& Sons.

Desimone, L. M. (2011). A primer on effective professional development. Phi Delta Kappan, 92(6), 68-71.

* Dessemontet, R., Bless, G., \& Morin, D. (2012). Effects of inclusion on the academic achievement and adaptive behaviour of children with intellectual disabilities. Journal of Intellectual Disability Research, 56(6), 579-587. doi:10.1111/j.1365-2788.2011.01497.x

* Elliott, S. (2008). The effect of teachers' attitude toward inclusion on the practice and success levels of children with and without disabilities in physical education. International Journal of Special Education, 23(3), 48-55.

Fuchs, W. W. (2010). Examining teachers' perceived barriers associated with inclusion. Southeastern Regional Association of Teacher Educators Journal, 19(1), 30-35.

Glasziou, P., Vandenbrouke, J., Chalmers, I., \& Lind, J. (2004). Assessing the quality of research. British Medical Journal, 328(7439), 39-41. doi:10.1136/bmj.328.7430.39

Government of Alberta. (2013). Teaching quality standard applicable to the provision of basic education in Alberta (Ministerial order \#016/97). Retrieved from https://education.alberta.ca/media/1626523/english-tqs-card-2013_3.pdf

Han, S. S., \& Weiss, B. (2005). Sustainability of teacher implementation of school-based mental health programs. Journal of Abnormal Child Psychology, 33(6), 665-679.

Harvey, M. W., Yssel, N., Bauserman, A. D., \& Merbler, J. B. (2010). Preservice teacher preparation for inclusion: An exploration of higher education teacher-training institutions. Remedial and Special Education, 31(1), 24-33. 
* Hong, S. B., Shaffer, L., \& Han, J. (2017). Reggio Emilia inspired learning groups: Relationships, communication, cognition and play. Early Childhood Education Journal, 45, 629-639.

* Hornstra, L., Denessen, E., Bakker, J., van den Bergh, L., \& Voeten, M. (2010). Teacher attitudes toward dyslexia: Effects on teacher expectations and the academic achievement of students with dyslexia. Journal of Learning Disabilities, 43(6), 515-529. doi:10.1177/0022219409355479

* Jimenez, B., Browder, D., Spooner, F., \& DiBase, W. (2012). Inclusive inquiry science using peermediated embedded instruction for students with moderate intellectual disability. Exceptional Children, 78(3), 301-317.

* Jorm, A., Kitchener, B., Sawyer, M., Scales, H., \& Cvetkovski, S. (2010). Mental health first aid training for high school teachers: A cluster randomized trial. Psychiatry, 10(51), 1-12.

* Knight, V., McKissick, B., \& Saunders, A. (2013). A review of technology-based interventions to teach academic skills to students with autism spectrum disorder. Journal of Autism and Developmental Disorders, 43(11), 2628-2648. doi:10.1007/s10803-013-1814-y

Koshy, V., \& Robinson, N. M. (2006). Too long neglected: Gifted young children. European Early Childhood Education Research Journal, 14(2), 113-126.

Loreman, T. (2007). Seven pillars of support for inclusive education: Moving from "Why?" to "How?" International Journal of Whole Schooling, 3(2), 22-38.

Mineo, B. A., Ziegler, W., Gill, S., \& Salkin, D. (2009). Engagement with electronic screen media among students with autism spectrum disorders. Journal of Autism and Developmental Disorders, 39(1), 172-187.

* Neil, A., \& Christensen, H. (2009). Efficacy and effectiveness of school-based prevention and early intervention programs for anxiety. Clinical Psychology Review, 29, 208-215. doi:10.1016/j.cpr.2009.01.002

* Nelson, C., Paul, K., Johnston, S., \& Kidder, J. (2017). Use of a creative dance intervention package to increase social engagement and play complexity of young children with autism spectrum disorder. Education and Training in Autism and Developmental Disabilities, 52(2), 170-185.

Ontario College of Teachers. (n.d.). Standards of practice [Web page]. Retrieved from http://www.oct.ca/public/professional-standards/standards-of-practice

* Östberg, M., \& Rydell, A. (2012). An efficacy study of a combined parent and teacher management training programme for children with ADHD. Nordic Journal of Psychiatry, 66(2), 123-130. doi:10.3109/08039488.2011.641587

* Parsons, S., Guldberg, K., MacLeod, A., Jones, G., Prunty, A., \& Balfe, T. (2011). International review of the evidence on best practice in educational provision for children on the autism spectrum. European Journal of Special Needs Education, 26(1), 47-63. doi:10.1080/08856257.2011.54353

* Pennington, R. (2010). Computer-assisted instruction for teaching academic skills to students with autism spectrum disorders: A review of literature. Focus on Autism and Other Developmental Disabilities, 24(4), 239-248. doi:10.1177/1088357610378291

* Pennington, R., \& Koehler, M. (2017). Effects of modelling, story templates, and self-graphing in the use of story elements by students with moderate intellectual disability. Education and Training in Autism and Developmental Disabilities, 52(3), 280-290.

Petersen, J. S. (2009). Myth 17: Gifted and talented individuals do not have unique social and emotional needs. Gifted Child Quarterly, 53(4), 280-282.

Pivik, J., McComas, J., \& Laflamme, M. (2002). Barriers and facilitators to inclusive education. Exceptional Children, 69(1), 97-107. 
Praisner, C. L. (2003). Attitudes of elementary school principals toward the inclusion of students with disabilities. Exceptional Children, 69(2), 135-145.

* Radley, K., Ford, W., Battaglia, A., \& McHugh, M. (2014). The effects of a social skills training package on social engagement of children with autism spectrum disorders in a generalized recess setting. Focus on Autism and Other Developmental Disabilities, 29(4), 216-229. doi: $10.1177 / 1088357614525660$

Reinke, W. M., Stormont, M., Herman, K. C., Puri, R., \& Goel, N. (2011). Supporting children's mental health in schools: Teacher perceptions of needs, roles, and barriers. School Psychology Quarterly, 26(1), 1-13.

Reis, S. M., \& Renzulli, J. S. (2009). Is there still a need for gifted education? An examination of current research. Learning and Individual Differences, 20(4), 308-317. doi:10.1016/j.lindif.2009.10.012

* Sainato, D., Morrison, R., Jung, S., Axe, J., \& Nixon, P. (2015). A comprehensive inclusion program for kindergarten children with autism spectrum disorder. Journal of Early Intervention, 37(3), 208-225. doi:10.1177/1053815115613836

Savolainen, H., Engelbrecht, P., Nel, M., \& Malinen, O.-P. (2012). Understanding teachers' attitudes and self-efficacy in inclusive education: Implications for pre-service and in-service teacher education. European Journal of Special Needs Education, 27(1), 51-68.

Seçer, Z. (2010). An analysis of the effects of in-service teacher training on Turkish preschool teachers' attitudes towards inclusion. International Journal of Early Years Education, 18(1), 43-53.

* Sherman, J., Rasmussen, C., \& Baydala, L. (2008). The impact of teacher factors on achievement and behavioural outcomes of children with attention deficit/hyperactivity disorder (ADHD): A review of the literature. Educational Research, 50(4), 347-360. doi:10.1080/00131880802499803

Shore, S., Rastelli, L. G., \& Grandin, T. (2006). Understanding autism for dummies. Hoboken, NJ: Wiley.

Shulman, L. S. (1987). Knowledge and teaching: Foundations of the new reform. Harvard Educational Review, 57(1), 1-22.

* Simpson, K., \& Keen, D. (2009). Teaching young children with autism graphic symbols embedded within an interactive song. Journal of Developmental and Physical Disabilities, 22(2), 165177. doi:10.1007/s10882-009-9173-5

* Simpson, K., \& Keen, D. (2011). Music interventions for children with autism: Narrative review of the literature. Journal of Autism and Developmental Disorders, 41, 1507-1514. doi: 10.1007/s10803-010-1172-y

* Solis, M., Vaughn, S., Swanson, E., \& McCulley, L. (2012). Collaborative models of instruction: The empirical foundations of inclusion and co-teaching. Psychology in the Schools, 49(5), 498510. doi:10.1002/pits. 21606

* Strogilos, V., \& Stefanidis, A. (2015). Contextual antecedents of co-teaching efficacy: Their influence on students with disabilities' learning progress, social participation and behaviour improvement. Teaching and Teacher Education, 47, 218-229. doi:10.1016/j.tate.2015.01.008

Swanson, H. L., \& Jerman, O. (2006). Math disabilities: A selective meta-analysis of the literature. Review of Educational Research, 76(2), 249-274.

Test, D. W., Mazzotti, V. L., Mustian, A. L., Fowler, C. H., Kortering, L., \& Kohler, P. (2009). Evidence-based secondary transition predictors for improving postschool outcomes for students with disabilities. Career Development for Exceptional Individuals, 32(3), 160-181. 
Tew, L., \& Lupart, J. (2008). Students with disabilities' perspectives of the role and impact of paraprofessionals in inclusive education settings. Policy and Practice in Intellectual Disabilities, 5(1), 39-46.

United Nations Educational, Scientific and Cultural Organization (UNESCO). (2009). Policy guidelines on inclusion in education (ED-2009/WS/31). Paris, France: Author.

Van Reusen, A. K., Shoho, A. R., \& Barker, K. S. (2001). High school teacher attitudes toward inclusion. The High School Journal, 84(2), 7-20.

Waddington, E. M., \& Reed, P. (2006). Parents' and local education authority officers' perceptions of the factors affecting the success of inclusion of pupils with autism spectrum disorders. International Journal of Special Education, 21(3), 151-164.

* Whalen, C., Moss, D., Ilan, A., Vaupel, M., Fielding, P., Macdonald, K., ... Symon, J. (2010). Efficacy of TeachTown: Basics computer-assisted intervention for the Intensive Comprehensive Autism Program in Los Angeles Unified School District. Autism, 14(3), 179197. doi:10.1177/1362361310363282

* Whitcomb, S., Bass, J., \& Luiselli, J. (2011). Effects of a computer-based early reading program

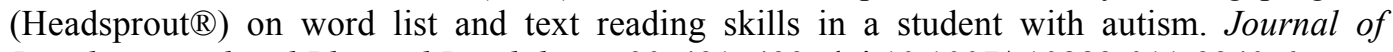
Developmental and Physical Disabilities, 23, 491-499. doi:10.1007/s10882-011-9240-6

Wilson, S. J., Lipsey, M. W., \& Derzon, J. H. (2003). The effects of school-based intervention programs on aggressive behavior: A meta-analysis. Journal of Consulting and Clinical Psychology, 71(1), 131-149.

\section{Authors' Note}

Correspondence concerning this article should be addressed to Daniel B. Robinson, 211 Xavier Hall, Antigonish, NS, B2G 2W5, Canada. Email: dan.robinson@stfx.ca 


\section{Appendix}

Teachers' Knowledge, Skills, Attitudes in Inclusive Education and Student Outcomes

\begin{tabular}{|c|c|c|c|c|c|}
\hline $\begin{array}{l}\text { Author(s) } \\
\text { (Year), Country }\end{array}$ & $\begin{array}{l}\text { Teacher } \\
\text { Variable(s) }\end{array}$ & $\begin{array}{l}\text { Student } \\
\text { Variable(s) }\end{array}$ & $\begin{array}{l}\text { Student } \\
\text { Outcome(s) }\end{array}$ & $\begin{array}{l}\text { Research Design and } \\
\text { Participants } \\
\text { (or Studies/Trials) }\end{array}$ & Research Results and Conclusions \\
\hline $\begin{array}{l}\text { Bottge et al. } \\
\text { (2015), USA }\end{array}$ & $\begin{array}{l}\text { knowledge } \\
\text { skills }\end{array}$ & $\begin{array}{l}\text { IDs, LDs, ASD, } \\
\text { other mental } \\
\text { health disorders } \\
\text { (emotional and } \\
\text { behavioural } \\
\text { disorder) }\end{array}$ & $\begin{array}{l}\text { academic } \\
\text { achievement }\end{array}$ & $\begin{array}{l}\text { experimental (between } \\
\text { subjects, post-test only) } \\
\text { students, } N=471 \\
\text { (134 with an exceptionality; } \\
\text { middle school) }\end{array}$ & $\begin{array}{l}\text { Co-teachers (general and special education) who } \\
\text { were trained in, and then implemented, EAl found that } \\
\text { students with and without MDs showed positive } \\
\text { learning outcomes. Still, despite removing a barrier to } \\
\text { special education teachers' active involvement (i.e., } \\
\text { training in EAI), many did not take an active role in } \\
\text { teaching content. }\end{array}$ \\
\hline $\begin{array}{l}\text { Calear \& } \\
\text { Christensen } \\
(2009), \text { AUS }\end{array}$ & $\begin{array}{l}\text { knowledge } \\
\text { skills }\end{array}$ & $\begin{array}{l}\text { other mental } \\
\text { health disorders } \\
\text { (depression) }\end{array}$ & $\begin{array}{l}\text { exceptionality- } \\
\text { related }\end{array}$ & $\begin{array}{l}\text { systematic review } \\
42 \text { studies/trials (related to } \\
28 \text { school-based programs) }\end{array}$ & $\begin{array}{l}\text { The majority of early intervention programs for } \\
\text { depression were delivered by a mental health } \\
\text { professional or graduate student. Teachers as leaders } \\
\text { were associated with fewer significant effects. }\end{array}$ \\
\hline $\begin{array}{l}\text { Coleman et al. } \\
\text { (2012), USA }\end{array}$ & $\begin{array}{l}\text { knowledge } \\
\text { skills }\end{array}$ & IDs, ASD & $\begin{array}{l}\text { academic } \\
\text { achievement }\end{array}$ & $\begin{array}{l}\text { correlational-descriptive } \\
\text { (case study) } \\
\text { students, } N=3 \\
\text { (elementary school) }\end{array}$ & $\begin{array}{l}\text { The effectiveness and efficiency of teacher-directed and } \\
\text { computer-assisted strategies were compared. Both } \\
\text { strategies were effective. However, the teacher-directed } \\
\text { strategy was more efficient (i.e., faster learning). }\end{array}$ \\
\hline $\begin{array}{l}\text { Dessemontet et } \\
\text { al. (2012), CHE }\end{array}$ & $\begin{array}{l}\text { knowledge } \\
\text { skills }\end{array}$ & IDs & $\begin{array}{l}\text { social well-being, } \\
\text { functional/life } \\
\text { skills, academic } \\
\text { achievement }\end{array}$ & $\begin{array}{l}\text { quasi-experimental } \\
\text { (between subjects, pre- and } \\
\text { post-test) } \\
\text { students, } N=68 \\
\text { (elementary school) }\end{array}$ & $\begin{array}{l}\text { Students taught by an MET without the specialist } \\
\text { knowledge or skills of an SET (though with } 4: 30 \text { to } \\
\text { 6:30 hr of weekly support from a SET) made slightly } \\
\text { more progress in literacy skills (though showed no } \\
\text { differences in mathematics skills or adaptive } \\
\text { behaviour). }\end{array}$ \\
\hline $\begin{array}{l}\text { Elliot (2008), } \\
\text { USA }\end{array}$ & attitudes & IDs & $\begin{array}{l}\text { academic } \\
\text { achievement }\end{array}$ & $\begin{array}{l}\text { correlational-descriptive } \\
\text { students, } N=100 \\
\text { (elementary school) } \\
\text { teachers, } N=20\end{array}$ & $\begin{array}{l}\text { There was a positive relationship between elementary } \\
\text { physical education teachers' attitudes toward } \\
\text { inclusion and the number of students' practice } \\
\text { attempts at tasks (in physical education), as well as } \\
\text { their level of success. }\end{array}$ \\
\hline
\end{tabular}


Appendix, cont'd

\begin{tabular}{|c|c|c|c|c|c|}
\hline $\begin{array}{l}\text { Author(s) } \\
\text { (Year), Country }\end{array}$ & $\begin{array}{l}\text { Teacher } \\
\text { Variable(s) }\end{array}$ & $\begin{array}{l}\text { Student } \\
\text { Variable(s) }\end{array}$ & $\begin{array}{l}\text { Student } \\
\text { Outcome(s) }\end{array}$ & $\begin{array}{l}\text { Research Design and } \\
\text { Participants } \\
\text { (or Studies/Trials) }\end{array}$ & Research Results and Conclusions \\
\hline $\begin{array}{l}\text { Hong et al. } \\
\text { (2017), USA }\end{array}$ & $\begin{array}{l}\text { knowledge } \\
\text { skills }\end{array}$ & $\begin{array}{l}\text { ASD (including } \\
\text { PDD-NOS*), } \\
\text { other mental } \\
\text { health disorders } \\
\text { (speech delay) }\end{array}$ & $\begin{array}{l}\text { social well-being, } \\
\text { functional/life } \\
\text { skills, academic } \\
\text { achievement }\end{array}$ & $\begin{array}{l}\text { correlational-descriptive } \\
\text { students, } N=5 \\
\text { ( } 2 \text { with a disability; } \\
\text { elementary school) }\end{array}$ & $\begin{array}{l}\text { Teachers who had the knowledge and skills necessary } \\
\text { to utilize a Reggio Emilia-inspired learning group found } \\
\text { equivocal results related to relationships and } \\
\text { communication skills (e.g., the student with PDD-NOS* } \\
\text { improved communication skills, while the student with a } \\
\text { speech delay showed no improvement). They also } \\
\text { found no improvement in cognitive skills. }\end{array}$ \\
\hline $\begin{array}{l}\text { Hornstra et al. } \\
\text { (2010), NLD }\end{array}$ & attitudes & LDs (dyslexia) & $\begin{array}{l}\text { academic } \\
\text { achievement }\end{array}$ & $\begin{array}{l}\text { correlational-descriptive } \\
\text { students, } N=307 \\
\text { (elementary school) } \\
\text { teachers, } N=30\end{array}$ & $\begin{array}{l}\text { Implicit teacher attitudes toward dyslexia were } \\
\text { positively related to teacher ratings of student } \\
\text { achievement on a writing task and also to student } \\
\text { achievement on standardized tests of spelling (but not } \\
\text { math) for those students with dyslexia. Explicit } \\
\text { attitudes were unrelated to all outcome measures. }\end{array}$ \\
\hline $\begin{array}{l}\text { Jimenez et al. } \\
\text { (2012), USA }\end{array}$ & $\begin{array}{l}\text { knowledge } \\
\text { skills }\end{array}$ & IDs & $\begin{array}{l}\text { academic } \\
\text { achievement }\end{array}$ & $\begin{array}{l}\text { quasi-experimental } \\
\text { (between subjects, pre- and } \\
\text { post-test) } \\
\text { students, } N=5 \text { (elementary } \\
\text { and middle school) }\end{array}$ & $\begin{array}{l}\text { All (five) students who were taught by teachers who } \\
\text { had the knowledge and skills to implement peer- } \\
\text { mediated time-delay instruction in an inclusive setting } \\
\text { increased their correct responses on assessment } \\
\text { tasks, though three required additional support from } \\
\text { an SET to reach mastery. }\end{array}$ \\
\hline $\begin{array}{l}\text { Jorm et al. } \\
\text { (2010), AUS }\end{array}$ & $\begin{array}{l}\text { knowledge } \\
\text { skills } \\
\text { attitudes }\end{array}$ & $\begin{array}{l}\text { other mental } \\
\text { health disorders } \\
\text { (general mental } \\
\text { health) }\end{array}$ & $\begin{array}{l}\text { exceptionality- } \\
\text { related }\end{array}$ & $\begin{array}{l}\text { quasi-experimental (within } \\
\text { subjects, pre- and post-test) } \\
\text { students, } N=327 \\
\text { (secondary school) } \\
\text { teachers, } N=14\end{array}$ & $\begin{array}{l}\text { Participation in a mental health first aid course was } \\
\text { found to have no effect upon teachers' individual } \\
\text { support toward students with mental health problems } \\
\text { or on student mental health. However, positive } \\
\text { outcomes were found-related, for example, to } \\
\text { teachers' knowledge, beliefs, and confidence in } \\
\text { providing help to students and colleagues. }\end{array}$ \\
\hline $\begin{array}{l}\text { Knight et al. } \\
\text { (2013), USA }\end{array}$ & $\begin{array}{l}\text { knowledge } \\
\text { skills }\end{array}$ & ASD & $\begin{array}{l}\text { academic } \\
\text { achievement }\end{array}$ & $\begin{array}{l}\text { systematic review } \\
25 \text { studies/trials }\end{array}$ & $\begin{array}{l}\text { Teaching competence related to instructional } \\
\text { technologies found only four "acceptable" quality } \\
\text { studies that demonstrated a relationship between } \\
\text { teaching and students' academic achievement. } \\
\text { Evidence suggests low-to-moderate evidence for } \\
\text { using technology-based interventions to teach } \\
\text { students with ASD. }\end{array}$ \\
\hline
\end{tabular}


Appendix, cont'd

\begin{tabular}{|c|c|c|c|c|c|}
\hline $\begin{array}{l}\text { Author(s) } \\
\text { (Year), Country }\end{array}$ & $\begin{array}{l}\text { Teacher } \\
\text { Variable(s) }\end{array}$ & $\begin{array}{l}\text { Student } \\
\text { Variable(s) }\end{array}$ & $\begin{array}{l}\text { Student } \\
\text { Outcome(s) }\end{array}$ & $\begin{array}{l}\text { Research Design and } \\
\text { Participants } \\
\text { (or Studies/Trials) }\end{array}$ & Research Results and Conclusions \\
\hline $\begin{array}{l}\text { Neil \& } \\
\text { Christensen } \\
(2009), \text { AUS }\end{array}$ & $\begin{array}{l}\text { knowledge } \\
\text { skills } \\
\text { attitudes }\end{array}$ & $\begin{array}{l}\text { other mental } \\
\text { health disorders } \\
\text { (anxiety) }\end{array}$ & $\begin{array}{l}\text { exceptionality- } \\
\text { related }\end{array}$ & $\begin{array}{l}\text { systematic review } \\
27 \text { studies/trials }\end{array}$ & $\begin{array}{l}\text { Compared to other leaders who led anxiety-reduction } \\
\text { programs (e.g., mental health professionals, graduates, } \\
\text { researchers), a higher percentage of trials involving } \\
\text { teachers as program leaders were successful in } \\
\text { significantly reducing symptoms of anxiety. }\end{array}$ \\
\hline $\begin{array}{l}\text { Nelson et al. } \\
\text { (2017), USA }\end{array}$ & $\begin{array}{l}\text { knowledge } \\
\text { skills }\end{array}$ & ASD & $\begin{array}{l}\text { social well-being, } \\
\text { functional/life skills }\end{array}$ & $\begin{array}{l}\text { correlational-descriptive } \\
\text { students, } N=3 \\
\text { (preschool) }\end{array}$ & $\begin{array}{l}\text { Preschool teachers with knowledge and skills to offer } \\
\text { a creative dance intervention (utilizing preferred play } \\
\text { materials, antecedent creative dance activities, and } \\
\text { priming of complex play) increased and improved play } \\
\text { skills for students with ASD. }\end{array}$ \\
\hline $\begin{array}{l}\text { Östberg \& Rydell } \\
\text { (2011), SWE }\end{array}$ & $\begin{array}{l}\text { knowledge } \\
\text { skills }\end{array}$ & $\begin{array}{l}\text { other mental } \\
\text { health disorders } \\
\text { (ADHD, ODD) }\end{array}$ & $\begin{array}{l}\text { exceptionality- } \\
\text { related }\end{array}$ & $\begin{array}{l}\text { experimental (between } \\
\text { subjects, pre-, post-, and } \\
\text { follow-up test) } \\
\text { parents, } N=61 \\
\text { teachers, } N=68\end{array}$ & $\begin{array}{l}\text { Participation in a combined parent-teacher manual- } \\
\text { based training program resulted in a reduction in the } \\
\text { number of elementary-aged children who met the } \\
\text { DSM-IV criteria for ADHD or ODD. }\end{array}$ \\
\hline $\begin{array}{l}\text { Parsons et al. } \\
\text { (2011), GBR }\end{array}$ & $\begin{array}{l}\text { knowledge } \\
\text { skills }\end{array}$ & ASD & $\begin{array}{l}\text { social well-being, } \\
\text { functional/life } \\
\text { skills, academic } \\
\text { achievement }\end{array}$ & $\begin{array}{l}\text { systematic review (empirical } \\
\text { and expert strands) } \\
92 \text { studies/trials and } \\
24 \text { reports/papers }\end{array}$ & $\begin{array}{l}\text { There is insufficiently strong evidence to suggest that } \\
\text { teachers' knowledge and skills related to one type of } \\
\text { intervention ought to be considered over any others. }\end{array}$ \\
\hline $\begin{array}{l}\text { Pennington } \\
\text { (2010), USA }\end{array}$ & $\begin{array}{l}\text { knowledge } \\
\text { skills }\end{array}$ & ASD & $\begin{array}{l}\text { academic } \\
\text { achievement }\end{array}$ & $\begin{array}{l}\text { systematic review } \\
15 \text { studies/trials }\end{array}$ & $\begin{array}{l}\text { CAI was found to be effective for teaching a limited } \\
\text { set of academic skills to individuals with ASD. } \\
\text { However, functional relations were found in few of the } \\
\text { single-case designs. }\end{array}$ \\
\hline $\begin{array}{l}\text { Pennington \& } \\
\text { Koehler (2017), } \\
\text { USA }\end{array}$ & $\begin{array}{l}\text { knowledge } \\
\text { skills }\end{array}$ & IDs & $\begin{array}{l}\text { academic } \\
\text { achievement }\end{array}$ & $\begin{array}{l}\text { quasi-experimental (within } \\
\text { subjects, pre- and post-test) } \\
\text { students, } N=3 \\
\text { (middle school) }\end{array}$ & $\begin{array}{l}\text { SETs with requisite knowledge and skills to introduce } \\
\text { an intervention package (comprising modeling, story } \\
\text { templates, and self-graphing) were able to have a } \\
\text { positive effect on students' (with moderate to severe } \\
\text { disabilities) targeted academic skills. }\end{array}$ \\
\hline
\end{tabular}


Appendix, cont'd

\begin{tabular}{|c|c|c|c|c|c|}
\hline $\begin{array}{l}\text { Author(s) } \\
\text { (Year), Country }\end{array}$ & $\begin{array}{l}\text { Teacher } \\
\text { Variable(s) }\end{array}$ & $\begin{array}{l}\text { Student } \\
\text { Variable(s) }\end{array}$ & $\begin{array}{l}\text { Student } \\
\text { Outcome(s) }\end{array}$ & $\begin{array}{l}\text { Research Design and } \\
\text { Participants (or } \\
\text { Studies/Trials) }\end{array}$ & Research Results and Conclusions \\
\hline $\begin{array}{l}\text { Radley et al. } \\
\text { (2014), USA }\end{array}$ & $\begin{array}{l}\text { knowledge } \\
\text { skills }\end{array}$ & ASD & $\begin{array}{l}\text { social well-being, } \\
\text { functional/life skills }\end{array}$ & $\begin{array}{l}\text { quasi-experimental (within } \\
\text { subjects, pre-, post-, and } \\
\text { follow-up test) } \\
\text { students, } N=4 \\
\text { (elementary school) }\end{array}$ & $\begin{array}{l}\text { Teachers with the requisite knowledge and skills to } \\
\text { introduce the Superheroes Social Skills program (a } \\
\text { practice-ready, multimedia social skills program) were } \\
\text { able to have a positive effect upon students' (with } \\
\text { ASD) social engagement. }\end{array}$ \\
\hline $\begin{array}{l}\text { Sainato et al. } \\
(2015), \text { USA }\end{array}$ & $\begin{array}{l}\text { knowledge } \\
\text { skills }\end{array}$ & $\begin{array}{l}\text { ASD (including } \\
\text { PDD-NOS*) }\end{array}$ & $\begin{array}{l}\text { functional/life } \\
\text { skills, academic } \\
\text { achievement }\end{array}$ & $\begin{array}{l}\text { quasi-experimental } \\
\text { (between subjects, pre- and } \\
\text { post-test) } \\
\text { students, } N=62 \\
\text { (elementary school) }\end{array}$ & $\begin{array}{l}\text { Teachers and assistants who were mentored and } \\
\text { trained to teach in a "model" inclusive class (e.g., } \\
\text { minimized "pull-out" activities, no assistants assigned } \\
\text { to individual students, general curriculum for all, etc.) } \\
\text { found no differences in test scores for their students } \\
\text { (than did a control group). However, the model group } \\
\text { did achieve higher scores in all skill domains (though } \\
\text { statistical significance was not found for adaptive } \\
\text { behaviour and spoken language). }\end{array}$ \\
\hline $\begin{array}{l}\text { Sherman et al. } \\
\text { (2008), CAN }\end{array}$ & $\begin{array}{l}\text { knowledge } \\
\text { skills } \\
\text { attitudes }\end{array}$ & $\begin{array}{l}\text { other mental } \\
\text { health disorders } \\
(A D H D)\end{array}$ & $\begin{array}{l}\text { academic } \\
\text { achievement, } \\
\text { exceptionality- } \\
\text { related }\end{array}$ & $\begin{array}{l}\text { systematic review } \\
14 \text { studies/trials }\end{array}$ & $\begin{array}{l}\text { Teachers with requisite knowledge, skills, and } \\
\text { attitudes to work with students with ADHD (e.g., } \\
\text { patience, knowledge of intervention techniques, ability } \\
\text { to collaborate with an interdisciplinary team, positive } \\
\text { attitude toward children with exceptionalities) can } \\
\text { have a positive effect upon student success. }\end{array}$ \\
\hline $\begin{array}{l}\text { Simpson \& Keen } \\
\text { (2009), AUS }\end{array}$ & $\begin{array}{l}\text { knowledge } \\
\text { skills }\end{array}$ & ASD & $\begin{array}{l}\text { academic } \\
\text { achievement }\end{array}$ & $\begin{array}{l}\text { quasi-experimental } \\
\text { (between subjects, pre-, } \\
\text { post-, and follow-up test) } \\
\text { students, } N=3\end{array}$ & $\begin{array}{l}\text { Teacher instruction that utilized music and interactive } \\
\text { song (as well as an interactive whiteboard) facilitated } \\
\text { learning for participants at intervention and follow- } \\
\text { up/maintenance). However, there is little opportunity } \\
\text { for generalization of these results to other contexts. }\end{array}$ \\
\hline $\begin{array}{l}\text { Simpson \& Kenn } \\
\text { (2011), AUS }\end{array}$ & $\begin{array}{l}\text { knowledge } \\
\text { skills }\end{array}$ & ASD & $\begin{array}{l}\text { social well-being, } \\
\text { functional/life skills }\end{array}$ & $\begin{array}{l}\text { scoping review } \\
20 \text { studies/trials }\end{array}$ & $\begin{array}{l}\text { There is limited evidence suggesting teachers with the } \\
\text { requisite knowledge and skills to utilize music as an } \\
\text { intervention (e.g., improvisational music therapy) can } \\
\text { facilitate social, communicative, and behavioural skills } \\
\text { in students with ASD. }\end{array}$ \\
\hline
\end{tabular}


Appendix, cont'd

\begin{tabular}{|c|c|c|c|c|c|}
\hline $\begin{array}{l}\text { Author(s) } \\
\text { (Year), Country }\end{array}$ & $\begin{array}{l}\text { Teacher } \\
\text { Variable(s) }\end{array}$ & $\begin{array}{l}\text { Student } \\
\text { Variable(s) }\end{array}$ & $\begin{array}{l}\text { Student } \\
\text { Outcome(s) }\end{array}$ & $\begin{array}{l}\text { Research Design and } \\
\text { Participants (or } \\
\text { Studies/Trials) }\end{array}$ & Research Results and Conclusions \\
\hline $\begin{array}{l}\text { Solis et al. } \\
\text { (2012), USA }\end{array}$ & $\begin{array}{l}\text { knowledge } \\
\text { skills }\end{array}$ & IDs & $\begin{array}{l}\text { academic } \\
\text { achievement }\end{array}$ & $\begin{array}{l}\text { scoping review (of reviews) } \\
6 \text { reviews }\end{array}$ & $\begin{array}{l}\text { Studies that focused upon inclusion models and } \\
\text { collaborative models of instruction (in which teachers } \\
\text { had the knowledge and skills to deliver those models) } \\
\text { found some positive results for students with } \\
\text { disabilities. However, due to methodological limitations, } \\
\text { conclusions about superiority of inclusion models } \\
\text { compared with pull-out models were not possible. }\end{array}$ \\
\hline $\begin{array}{l}\text { Strogilos \& } \\
\text { Stefanidis } \\
(2015), \text { GRC }\end{array}$ & attitudes & $\begin{array}{l}\text { other mental } \\
\text { health disorders } \\
\text { (disabilities, } \\
\text { generally) }\end{array}$ & $\begin{array}{l}\text { social well-being, } \\
\text { functional/life } \\
\text { skills, academic } \\
\text { achievement }\end{array}$ & $\begin{array}{l}\text { descriptive-correlational } \\
\text { teachers, } N=400\end{array}$ & $\begin{array}{l}\text { Co-teachers who have favourable attitudes related to } \\
\text { inclusion (e.g., who favour the participation of } \\
\text { students with disabilities in mixed ability groups) tend } \\
\text { to agree that the learning of students with disabilities } \\
\text { is improved. }\end{array}$ \\
\hline $\begin{array}{l}\text { Whalen et al. } \\
\text { (2010), USA }\end{array}$ & $\begin{array}{l}\text { knowledge } \\
\text { skills }\end{array}$ & ASD & $\begin{array}{l}\text { academic } \\
\text { achievement }\end{array}$ & $\begin{array}{l}\text { quasi-experimental } \\
\text { (between subjects, pre- and } \\
\text { post-test) } \\
\text { students, } N=47 \text { (preschool } \\
\text { and elementary school) }\end{array}$ & $\begin{array}{l}\text { Students taught by teachers who had the requisite } \\
\text { knowledge and skills to teach using TeachTown: } \\
\text { Basics, a CAI program, showed a greater } \\
\text { improvement overall on language and cognitive } \\
\text { measure outcomes. }\end{array}$ \\
\hline $\begin{array}{l}\text { Whitcomb et al. } \\
\text { (2011), USA }\end{array}$ & $\begin{array}{l}\text { knowledge } \\
\text { skills }\end{array}$ & ASD & $\begin{array}{l}\text { academic } \\
\text { achievement }\end{array}$ & $\begin{array}{l}\text { quasi-experimental (single } \\
\text { subject, pre- and post-test) } \\
\text { students, } N=1 \\
\text { (elementary school) }\end{array}$ & $\begin{array}{l}\text { Students taught by teachers who had the requisite } \\
\text { knowledge and skills to teach using Headsprout, a } \\
\text { CAl program, showed an improvement in reading } \\
\text { accuracy and reading skills. }\end{array}$ \\
\hline
\end{tabular}

* PDD-NOS, pervasive developmental disorder-not otherwise specified 